JPPUMA: Jurnal Ilmu Pemerintahan dan Sosial Politik UMA (Journal of Governance and Political Social UMA)

\title{
Perumusan Strategi Pengelolaan Pasar Tradisional di Kabupaten Sumedang
}

\section{Formulation of Strategy of Traditional Market Management in District Sumedang}

\author{
Arip Rahman Sudrajat*, Asep Sumaryana, Rd. Ahmad Buchari \& Tahjan \\ Pascasarjana Administrasi Publik, Fakultas Ilmu Sosial dan Ilmu Politik \\ Universitas Padjadjaran, Indonesia.
}

\begin{abstract}
Abstrak
Penelitian ini mengenai perumusan strategi dalam mengelola Pasar Tradisional di Kabupaten Sumedang. Permasalahan dalam perumusan strategi masih belum sepenuhnya mengikuti perkembangan kondisi dan situasi faktual, masih rendahnya pengetahuan para pedagang mengenai produk dan strategi pemasaran dan revitalisasi pasar tradisional hingga saat ini ternyata belum mampu memberikan daya saing terhadap pasar modern. Dalam membahas perumusan strategi pengelolaan Pasar Tradisional di Kabupaten Sumedang mencoba menggunakan tahapan dalam manajemen strategis yang mengacu pada salah satu elemen dari empat elemen dasar dari manajemen strategis menurut Hunger dan Wheelen (2003: 4), bahwa manajemen strategis mencakup pengamatan lingkungan, perumusan strategi, implementasi strategi, serta evaluasi dan pengendalian. Metode yang digunakan dalam penelitian ini adalah menggunakan pendekatan kualitatif. Hasil penelitian menunjukan bahwa perumusan strategi pengelolaan Pasar Tradisional di Kabupaten Sumedang pada saat ini belum sesuai dengan elemen pada manajemen strategis secara utuh, dimana dalam merumuskan dan menetapkan strategi, para pimpinan belum memiliki analisis yang tepat tentang kekuatan dan kelemahan yang dimiliki oleh Pemerintah Kabupaten Sumedang pada khususnya Disperindag Kabupaten Sumedang itu sendiri, serta belum memberdayakan keunggulan yang dimiliki Pemerintah Kabupaten Sumedang yang dikaitkan dengan tantangan lingkungan, dan belum sepenuhnya dirancang untuk memastikan bahwa tujuan utama pengelolaan Pasar Tradisional di Kabupaten Sumedang dapat dicapai.

Kata Kunci: Perumusan Strategi, Pengelolaan Pasar Tradisional.
\end{abstract}

\begin{abstract}
This research is about the formulation of strategy in managing Traditional Market in Sumedang Regency. The problems in the formulation of the strategy still not fully follow the factual condition and condition, the low knowledge of the traders on the products and marketing strategies and revitalization of traditional markets until now has not been able to provide competitiveness to the modern market. In discussing the formulation of Traditional Market management strategy in Sumedang Regency try to use stages in strategic management which refers to one element of the four basic elements of strategic management according to Hunger and Wheelen (2003: 4), that strategic management includes environmental observation, strategy formulation, strategy, and evaluation and control. The method used in this research is using qualitative approach. The result of the research shows that the formulation of Strategy of Traditional Market Strategy in Sumedang Regency is not yet in accordance with the element in the strategic management as a whole, where in formulating and setting the strategy, the leaders do not have proper analysis about the strength and weakness possessed by Sumedang Regency Government especially the Disperindag of Sumedang Regency itself, and has not yet empowered the advantages of Sumedang District Government that is associated with environmental challenges, and has not been fully designed to ensure that the main objective of Traditional Market management in Sumedang Regency can be achieved.

Keywords: Strategy Formulation, Traditional Market Management.
\end{abstract}

How to Cite: Sudrajat, A.R., Sumaryana, A. \& Buchari, R.A. \& Tahjan. (2018). Perumusan Strategi Pengelolaan Pasar Tradisional di Kabupaten Sumedang. JPPUMA: Jurnal Ilmu Pemerintahan dan Sosial Politik UMA, 6 (1): 53-67.

DOI: http://dx.doi.org/10.31289/jppuma.v6i1.1600

${ }^{*}$ Corresponding author: ISSN 2549-166o (Print)

E-mail: arip15002@mail.unpad.ac.id ISSN 2550-1305 (Online) 


\section{PENDAHULUAN}

Pasar tradisional merupakan salah satu fasilitas umum yang keberadaannya sangat penting dan dibutuhkan oleh masyarakat, khususnya untuk memenuhi salah satu kebutuhan pokok manusia, yaitu dalam hal pangan dan sandang. Di tengah pembangunan bangsa Indonesia yang lebih berpihak pada pelaku usaha menengah ke bawah, peran pasar tradisional sangatlah penting. Sayangnya peran pasar tradisional yang semestinya menjadi pilar pembangunan ekonomi kerakyatan, justru terabaikan.

Desakan modernisasi dan globalisme ekonomi, memojokkan pasar tradisional pada titik ketidakberdayaan, sehingga sulit untuk maju. Padahal hilangnya pasar-pasar tradisional akan berdampak pada pertumbuhan ekonomi suatu daerah, seperti bertambahnya pengangguran, menurunnya daya beli akibat tingkat pendapatan per kapita yang semakin kecil, melemahnya sektorsektor perdagangan informal, terhambatnya arus ditribusi kebutuhan pokok, dan lain-lain yang pada akhirnya bermuara pada marginalisasi ekonomi pasar tradisional.

Karena itu keberpihakan pemerintah daerah sangat dibutuhkan untuk menjaga keseimbangan jalannya perekonomian. Pemerintah daerah semestinya peka dan peduli untuk melindungi pasar tradisional yang memang masih dibutuhkan masyarakat, terutama masyarakat kelas menengah ke bawah dan juga masyarakat di daerah pinggiran atau pedesaan.
Keberadaan pasar tradisional juga semestinya mendapatkan perhatian lebih serius dari pemerintah daerah. Karena pada hakekatnya aset pasar adalah milik pemerintah daerah, sedangkan pedagang hanya memegang hak pakai. Pemerintah daerah memiliki tanggungjawab moral untuk melindungi, membangun, dan memberdayakan pasar tradisional sebagai ruang kegiatan ekonomi dalam rangka mencapai kesejahteraan masyarakat.

Adapun yang dimasudkan dengan pasar tradisional adalah sekumpulan pembeli dan penjual dari sebuah barang atau jasa tertentu. Para pembeli sebagai sebuah kelompok, menentukan permintaan terhadap produk, dan para penjual sebagai kelompok menentukan penawaran terhadap produk (Mankiw, 2003: 82). Berdasarkan pada kelas atau mutu dari pelayanan yang diberikan oleh suatu pasar, dapat digolongkan menjadi dua kategori, yaitu pasar tradisional dan pasar modern. Berdasarkan Perpres No. 112 Tahun 2007 Pasal 1, pengertian pasar tradisional adalah pasar yang dibangun dan dikelola oleh pemerintah, pemerintah daerah, swasta, Badan Usaha Milik Negara dan Badan Usaha Milik Daerah, termasuk kerjasama dengan tempat usaha berupa toko, kios, los dan tenda yang dimiliki atau dikelola oleh pedagang kecil, menengah, swadaya masyarakat atau koperasi dengan usaha skala kecil, modal kecil, dan dengan proses jual beli barang dagangan melalui tawar-menawar.

Sedangkan pasar modern adalah pasar yang dibangun oleh pemerintah, swasta, atau 
koperasi yang dalam bentuknya berupa mall, supermarket, department store, shopping centre, waralaba, toko mini swalayan, pasar serba ada, toko serba ada dan sebagainya dimana pengelolaannya dilaksanakan secara modern, yang mengutamakan kenyamanan berbelanja dengan manajemen berada di satu tangan, bermodal relatif kuat dan dilengkapi dengan label harga yang pasti.

Semakin hari semakin banyak masyarakat yang meninggalkan pasar tradisional dan beralih ke pasar modern yang semakin hari semakin menjamur. Kini pasar tradisional semakin terpinggirkan dan sepi pengunjung, sementara pasar-pasar modern terus bergeliat dan meningkatkan kualitas serta pelayanannya untuk semakin memuaskan para konsumennya. Sedangkan pendapatan para pedagang pasar tradisional semakin hari semakin merosot, bahkan hingga gulung tikar, bahkan sampai menurunkan kegiatan ekonomi masyarakat kelas menengah ke bawah, karena mayoritas pedagang ini adalah masyarakat kelas menengah ke bawah.

Kini sangat mudah bagi masyarakat untuk menjumpai minimarket, supermarket, dan hypermarket di sekitar tempat tinggal kita. Barang yang dijual disini memiliki variasi jenis yang beragam. Selain menyediakan barangbarang lokal, pasar modern juga menyediakan barang impor. Pasar modern juga memberikan pelayanan yang baik dengan adanya fasilitas pendingin udara dan penampilan yang bersih yang membuat konsumen semakin nyaman ketika berbelanja. Dengan berbagai macam kelebihan yang tidak dimiliki pasar tradisional, dan kelayakan yang ditawarkan, tentu pasar-pasar modern akan dengan mudah menarik perhatian masyarakat.

Kondisi pasar tradisional yang terpuruk, membuat banyak masyarakat di Indonesia lebih memilih berbelanja di pasar modern yang lebih tertata, bersih dan nyaman. Karena itu, untuk menjaga eksistensi pasar tradisional, pemerintah pusat mengeluarkan Peraturan Menteri Dalam Negeri Nomor 20 tahun 2012 tentang pengelolaan dan pemberdayaan pasar tradisional. Dan Peraturan Menteri Perdagangan Republik Indonesia Nomor: 70/M-Dag/Per/12/2013 Tentang Pedoman Penataan Dan Pembinaan Pasar Tradisional, Pusat Perbelanjaan Dan Toko Modern.

Berbagai peraturan yang dikeluarkan oleh pemerintah pusat tersebut, diderivasi oleh pemerintah daerah dalam bentuk peraturan daerah sesuai dengan kebutuhan masing-masing daerah. Misalnya saja di daerah Kabupaten Sumedang, Bupati mengeluarkan Perda nomor 3 tahun 2014 sebagai dasar hukum dalam pelaksanaan dalam hal mengelola pasar tradisional dengan baik. Upaya pemerintah pusat maupun daerah untuk tetap mempertahankan pasar tradisional demikian kuatnya. Namun persoalannya adalah, pasar tradisional masih identik dengan tempat yang kotor, semrawut, sumpek dan beraroma tidak sedap yang disebabkan oleh penumpukan sampah yang bertebaran di mana-mana. Sebagaimana hasil observasi awal pada beberapa pasar tradisional yang ada di Kabupaten Sumedang diantaranya Pasar Conggeang, Pasar Buahdua, 
Pasar Ujungjaya, dan Pasar Tanjungsari masih dapat dikategorikan sebagai pasar yang kurang terjaga kebersihan dan kerapihannya, karena pasar tersebut masih terdapat penjual yang kurang teratur, dan masih terdapat sampah yang berserakan pada waktu pasar sedang ramai pengunjung.

Berdasarkan keterangan dari Kepala UPT Pasar di Wilayah Tengah (Pasar Inpres, PKKS, Pasar Wado, Pasar Darmaraja), permasalahan lainnya adalah faktor kurangnya kesadaran dari para pedagang yang masih berdesakan sampai jualannya memakan badan jalan dalam pasar. Selain itu, pengunjung dan penduduk di sekitar pasar, dalam membuang sampah tidak pada tempatnya, menyebabkan meningkatnya jumlah sampah yang berserakan di sekitar pasar. Dan kurang adanya kesadaran juru parkir yang menggunakan badan jalan untuk lahan parkir, sehingga tidak jarang menimbulkan kemacetan, hal tersebut tambah membuat keadaan pasar terlihat semakin tidak tertib.

Meskipun keadaan pasar tradisional sedemikian parah, namun tetap saja keberadaan pasar tradisional tidak mungkin ditiadakan. Karena sebagian besar masyarakat masih berada dalam kondisi ekonomi menengah ke bawah, sehingga tidak memiliki daya beli yang cukup besar untuk terus-menerus berbelanja di pasar-pasar modern. Menginggat hal tersebut, pemerintah Kabupaten Sumedang berupaya melakukan upaya-upaya untuk mewujudkan suatu pengelolaan pasar tradisional yang sesuai dengan ekspektasi masyarakat dengan jalan program revitalisasi pasar tradisional dengan menjalin kerjasama bersama investor untuk merevitalisasi sejumlah pasar tradisional, seperti Pasar Wado, Pasar Darmaraja, Pasar Tanjungsari dan Pasar Inpres Sumedang.

Tujuan revitalisasi pasar dengan konsep pasar tradisional yang berdaya saing dengan pasar modern merupakan suatu cara untuk memajukan pasar tradisional, sehingga dapat meningkatkan volume dan nilai transaksi usaha serta terbangunnya sinergitas dan interaksi ekonomi yang seimbang dengan pasar modern. Dengan adanya renovasi dan pengelolaan yang baik, serta dilengkapinya berbagai fasilitas yang memadai, maka pasar tradisional akan siap bersaing dengan pasar modern. Namun, menurut keterangan dari Ketua Ikatan Kerukunan Warga Pedagang Pasar (IKWAPA) Sumedang, upaya ini ternyata berujung pada permasalahan baru, karena banyak pedagang lama yang tersingkir akibat ketidakmampuan membeli kios baru, bahkan ada pula pedagang yang memilih berjualan di luar kompleks pasar karena di dalam tidak laku.

Sebagaimana telah disebutkan di atas, secara normatif pengelolaan pasar telah diwadahi dalam perda nomor 3 tahun 2014 tentang pengelolaan dan pemberdayaan pasar tradisional, serta penataan pusat perbelanjaan dan toko modern di Kabupaten Sumedang. Berdasarkan hasil observasi awal dan penelaahan dokumen-dokumen terkait, ditemukan fakta bahwa pelaksanaan dari perda tersebut belum sesuai dengan apa yang dituangkan dalam Perda Nomor 3 Tahun 
2014, pengelolaan dan pemberdayaan pasar tradisional, serta penataan pusat perbelanjaan dan toko modern di Kabupaten Sumedang masih jauh dari harapan masyarakat.

Berdasarkan keterangan dari Kepala UPT Pasar Wilayah Kota (Pasar Tanjungsari dan Pasar Cimanggung), ketentuan yang paling banyak dilanggar pada pendirian pusat perbelanjaan dan toko modern adalah dalam hal zonasi atau penentuan jarak, bahwa toko modern dapat dibangun dengan jarak radius terdekat dari pasar tradisional minimal 2.000 meter. Ketentuan tersebut belum maksimal dilaksanakan dengan salah satu contoh toko Busana di Jalan Raya Tanjungsari - Sumedang berdekatan dengan Pasar Tradisional Tanjungsari dengan jarak kurang lebih 150 meter, dan beberapa minimarket di daerah pusat Kabupaten Sumedang berkisar jaraknya 250 - 350 meter. Hal itu jelas tidak sesuai aturan yang tertuang dalam Perda Nomor 3 Tahun 2014 pengelolaan dan pemberdayaan pasar tradisional serta penataan pusat perbelanjaan dan toko modern di Kabupaten Sumedang tepatnya pada Pasal 49 ayat 11 butir a.

Selain permasalahan umum yang dideskripsikan di atas, apabila dilihat secara komprehensif, perda nomor 3 tahun 2014 pengelolaan dan pemberdayaan pasar tradisional serta penataan pusat perbelanjaan dan toko modern di Kabupaten Sumedang, belum dapat mengatasi permasalahan yang terjadi. Berdasarkan hasil wawancara dengan Kabid Perdagangan di Dinas Koperasi, UKM, Perdagangan dan Perindustrian Kabupaten
Sumedang terdapat beberapa permasalahan yang terungkap bahwa dalam perumusan strategi masih belum sepenuhnya mengikuti perkembangan kondisi dan situasi faktual, artinya masih menjalankan dari perumusan strategi yang sudah ada sebelumnya. Salah satu permasalahan yang ada adalah dalam bentuk kebijakan teknis yang masih belum adanya acuan yang baru, sehingga hanya mengandalkan pada kebijakan yang bersifat umum seperti halnya mengacu ke perda saja.

Melihat kondisi tersebut, pengelolaan pasar memerlukan desain dan strategi managemen yang komprehensif dan multisektoral. Peritel di pasar tradisional perlu mengantisipasi perubahan perilaku konsumennya, tuntutan konsumen dalam pelayanan pasar yang profesional, dan persaingan bisnis diantara mereka. Karena dengan strategi pengelolaan yang baik, maka Pasar Tradisional di Kabupaten Sumedang siap bersaing dengan pasar modern, serta dapat tetap survive.

Persepsi konsumen tentang hal-hal yang dipertimbangkan dalam mengambil keputusan belanja di pasar tradisional, perlu dikaji dengan seksama, sehingga dari sini dapat dianalisis variabel lingkungan eksternal yang paling dominan dalam pengambilan keputusan belanja konsumen di pasar tradisional antara faktor budaya dan faktor sosial.

Oleh karena itu, untuk tetap memelihara daya beli masyarakat di pasar tradisional, dan memelihara kebersihan, keamanan serta kenyamanan pasar tradisional, maka perlu dilakukan perumusan strategi khusus 
pengelolaan pasar tradisional di Kabupaten Sumedang. Agar pengelolaan pasar tradisional tidak semakin memarginalkan para pedagang tradisional, tetapi justru meningkatkan daya saing mereka.

\section{METODE PENELITIAN}

Dalam penelitian yang digunakan adalah metode penelitian kualitatif atau sering disebut dengan metode naturalistik karena penelitiannya dilakukan pada kondisi yang alamiah (Natural Setting) dan hasil dari penelitian kualitatif lebih menekankan pada makna daripada generalisasi. Sugiyono (2014) mengemukakan bahwa:

"Metode penelitian kualitatif adalah metode penelitian yang digunakan untuk meneliti pada kondisi objek yang ilmiah, (sebagai lawannya adalah eksperimen) dimana peneliti adalah sebagai instrument kunci, teknik pengumpulan data dilakukan secara triangulasi (gabungan), analisis data bersifat induktif, dan hasil penelitian kualitatif lebih menekankan makna daripada generalisasi".

Metode penelitian kualitatif ini digunakan karena dianggap lebih mudah dalam menyesuaikan dengan kenyataankenyataan yang dihadapi dilapangan. Hal ini sesuai dengan pendapat Moleong (2014) sebagai berikut:

Metode kualitatif ini digunakan karena beberapa pertimbangan, yaitu:

1. Dapat menyesuaikan metode kualitatif lebih mudah apabila berhadapan dengan kenyataan-kenyataan ganda.
2. Metode ini menyajikan secara langsung hakekat hubungan antara penelitian dan responden.

3. Metode ini lebih dapat menyesuaikan diri dengan banyak penjaman pengaruh bersama dan terhadap pola-pola nilai yang dihadapi.

\section{HASIL DAN PEMBAHASAN}

Perumusan strategi merupakan pengembangan rencana jangka panjang untuk manajemen yang efektif dalam mengelola berbagai kesempatan dan berbagai ancaman lingkungan, dilihat dari kekuatan dan kelemahan Dinas Koperasi, UKM, Perdagangan dan Perindustrian Kabupaten Sumedang.

\section{Misi}

Misi yang ditetapkan oleh Dinas Koperasi, UKM, Perdagangan dan Perindustrian Kabupaten Sumedang mendefinisikan tujuan mendasar dan unik yang membedakan Dinas Koperasi, UKM, Perdagangan dan Perindustrian Kabupaten Sumedang dengan organisasi yang lainnya. Misi Dinas Koperasi, UKM, Perdagangan dan Perindustrian Kabupaten Sumedang secara umum tercantum dalam Renstra 2014-2018 Dinas Koperasi, UKM, Perdagangan dan Perindustrian Kabupaten Sumedang.

Pelaksanaan misi Dinas Koperasi UKM Perdagangan dan Perindustrian dalam mendukung pelaksanaan manajemen strategis pengelolaan Pasar Tradisional di Kabupaten Sumedang pada dasarnya adalah berkeinginan memberikan pelayanan 24 jam dari segi keamanannya, termasuk juga aspek 
kebersihannya dalam pengelolaan pasar tradisional. Di harapkan misi ini masyarakat memberikan kepercayaan terhadap pasar tradisional

Menurut Drucker (2000), "pada dasarnya misi merupakan alasan mendasar eksistensi suatu organisasi”. Pernyataan misi organisasi, terutama di tingkat unit bisnis menentukan batas dan maksud aktivitas bisnis perusahaan. Dengan demikian, peneliti dapat menganalisis bahwa para pimpinan Dinas Koperasi, UKM, Perdagangan dan Perindustrian Kabupaten Sumedang, dalam menetapkan misi untuk melaksanakan manajemen strategis ternyata belum spenuhnya memperhatikan beberapa faktor yang sifatnya kritikal, yang berarti dalam menentukan misi pokok manajemen strategis pengelolaan Pasar Tradisional di Kabupaten Sumedang belum tanggap terhadap kondisi faktual di lapangan yang tentunya bersifat dinamis. Untuk itu perlunya pengkajian ulang untuk penyempurnaan misi yang diharapkan. Dalam merumuskan dan menetapkan misi, para pimpinan Dinas Koperasi, UKM, Perdagangan dan Perindustrian Kabupaten Sumedang juga harus mengembangkan profil tertentu bagi organisasi. Selanjutnya, pengenalan lingkungan Dinas Koperasi, UKM, Perdagangan dan Perindustrian Kabupaten Sumedang untuk dapat berinteraksi, misi ini idealnya merupakan analisis yang memperhitungkan kekuatan dan kelemahan, peluang dan ancaman yang dimiliki oleh Dinas Koperasi, UKM, Perdagangan dan
Perindustrian Kabupaten Sumedang itu sendiri.

Seharusnya misi bagi manajemen Dinas Koperasi, UKM, Perdagangan dan Perindustrian Kabupaten Sumedang ialah rencana berskala besar yang berorientasi jangkauan masa depan yang jauh, serta ditetapkan sedemikian rupa sehingga memungkinkan Dinas Koperasi, UKM, Perdagangan dan Perindustrian Kabupaten Sumedang berinteraksi secara efektif dengan lingkungan dalam kondisi yang terus berubah yang kesemuanya diarahkan pada optimalisasi pencapaian tujuan, dan berbagai sasaran Dinas Koperasi, UKM, Perdagangan dan Perindustrian Kabupaten Sumedang yang bersangkutan. Sebagaiamana yang di ungkapkan Drucker (2000), "pada dasarnya misi merupakan alasan mendasar eksistensi suatu organisasi".

Sebagai realisasi yang baik, misi manajemen strategis yang dilakukan oleh Dinas Koperasi, UKM, Perdagangan dan Perindustrian Kabupaten Sumedang dalam mengelola pasar tradisional seharusnya dirumuskan dalam kalimat yang kandungan maknanya khusus dan merujuk pada tindakan spesifik atau rinci sebagai penjabaran dari visi yang direalisasikan dalam bentuk program kegiatan/kerja dan dapat dirumuskan atau diidentifikasi ukuran kinerjanya. Kegagalan dalam merumuskan ukuran kinerja yang sesuai, ternyata menjadi penyebab kegagalan Dinas Koperasi, UKM, Perdagangan dan Perindustrian Kabupaten Sumedang dalam mencapai misinya. Dalam proses manajemen 
strategis, arus informasi mencakup data historis, data saat ini, dan data ramalan tentang operasi dan lingkungan pasar tradisional di Kabupaten Sumedang, sangat dibutuhkan oleh Dinas Koperasi, UKM, Perdagangan dan Perindustrian Kabupaten Sumedang.

\section{Tujuan}

Tujuan

Dinas Koperasi, UKM,

Perdagangan dan Perindustrian Kabupaten Sumedang merupakan hasil akhir aktivitas perencanaan dalam mengelola pasar tradisional. Tujuan manajemen strategis yang dilakukan oleh Dinas Koperasi, UKM, Perdagangan dan Perindustrian Kabupaten Sumedang dalam mengelola pasar tradisional menciptakan pasar tradisional yang bersih, tertib, aman, nyaman dan berdaya saing dengan pusat perbelanjaan dan toko modern. Pencapaian tujuan Dinas Koperasi, UKM, Perdagangan dan Perindustrian Kabupaten Sumedang tersebut merupakan hasil dari penyelesaian misi dalam manajemen strategis yang dilakukan oleh Dinas Koperasi, UKM, Perdagangan dan Perindustrian Kabupaten Sumedang dalam mengelola pasar tradisional.

Pencapaian tujuan yang telah di tetapkan oleh Dinas Koperasi UKM Perdagangan dan Perindustrian dalam mendukung pelaksanaan manajemen strategis pengelolaan Pasar Tradisional di Kabupaten Sumedang dapat dilihat dari Renstra yang sudah tercapai dengan baik. Pada tahun 2018 ini Dinas Koperasi, UKM, Perdagangan dan Perindustrian Kabupaten Sumedang mencapai misi dalam mengelola pasar tradisional di
Kabupaten Sumedang sesuai dengan Renstra yang di buat oleh Pemerintah Kabupaten Sumedang periode tahun 2013-2018 ini. Selain itu pencapaian tujuan pengelolaan Pasar Tradisional di Kabupaten Sumedang diakui ternyata memang ada yang berorientasi pencapaian target PAD. Dari segi pelayanan kebersihan sudah dilaksanakan setiap hari 24 jam dan demikian pula dalam aspek keamanaan. Dari segi pelayaan Pasar Tradisional di Kabupaten Sumedang sudah baik, hanya dari aspek sarana prasarana masih kurang karena terbentur dengan anggaran. Seperti pasar impres itu kondisinya masih kotor, seharusnya tidak demikian. Hal ini akibat dari terjadinya pertentangan dalam hal penganggaran di Pemerintah Kabupaten Sumedang yang melibatkan pihak Pemerintah Kabupaten Sumedang dan DPRD Kabupaten Sumedang, sehingga masih banyak pasar yang kotor, tetapi dari 9 pasar tradisional di Kabupaten Sumedang sekarang sudah semakin baik kondisinya.

Berdasar pada data bahwa upaya pencapaian tujuan dalam rangka melaksanakan manajemen strategis yang dilakukan oleh Dinas Koperasi, UKM, Perdagangan dan Perindustrian Kabupaten Sumedang dalam mengelola pasar tradisional belum tercapai, karena tujuan perbaikan ke sembilan (9) pasar tradisional yang ada di Kabupaten Sumedang baru empat (4) pasar atau sekitar 30\% yang dapat direvitalisasi. Belum lagi tujuan dalam peningkatan kualiatas SDM dan kesadaran para pedagang Pasar Tradisional di Kabupaten Sumedang yang 
masih bervariatif. Apabila mengutip pendapat Suwandiyanto (2010) seharusnya tujuan dari manajemen strategis dalam pengelolaan pasar tradisional yaitu memberikan arah pencapaian tujuan Dinas Koperasi, UKM, Perdagangan dan Perindustrian Kabupaten Sumedang. Dalam hal ini para pimpinan Dinas Koperasi, UKM, Perdagangan dan Perindustrian Kabupaten Sumedang harus mampu menunjukan kepada semua pihak kemana arah tujuan manajemen strategis yang dilakukan oleh Dinas Koperasi, UKM, Perdagangan dan Perindustrian Kabupaten Sumedang dalam mengelola pasar tradisional, karena arah yang jelas dapat dijadikan landasan untuk pengendalian dan mengevaluasi keberhasilan dalam mengelola pasar tradisional.

Selanjutnya para pimpinan Dinas Koperasi, UKM, Perdagangan dan Perindustrian Kabupaten Sumedang harus membantu memikirkan kepentingan berbagai pihak, dimana manajemen strategis yang dilakukan oleh Dinas Koperasi, UKM, Perdagangan dan Perindustrian Kabupaten Sumedang dalam mengelola pasar tradisional harus mempertemukan kebutuhan berbagai pihak, pemasok, para pegawai, para pedagang, pihak perbankan, dan masyarakat Kabupaten Sumedang lainnya yang memegang peranan terhadap sukses atau gagalnya manajemen strategis yang dilakukan oleh Dinas Koperasi, UKM, Perdagangan dan Perindustrian Kabupaten Sumedang dalam mengelola pasar tradisional.

Para pimpinan Dinas Koperasi, UKM, Perdagangan dan Perindustrian Kabupaten
Sumedang juga harus mengantisipasi setiap perubahan kembali secara merata, dimana manajemen strategis memungkinkan para pimpinan Dinas Koperasi, UKM, Perdagangan dan Perindustrian Kabupaten Sumedang untuk mengantisipasi perubahan dan menyiapkan pedoman dan pengendalian, sehingga dapat memperluas kerangka waktu berpikir mereka secara perspektif dan memahami kontribusi yang baik untuk hari ini dan hari esok.

Terakhir manajemen strategis yang dilakukan oleh Dinas Koperasi, UKM, Perdagangan dan Perindustrian Kabupaten Sumedang dalam mengelola pasar tradisional ini berhubungan dengan efisiensi dan efektivitas, dimana tanggung jawab para pimpinan Dinas Koperasi, UKM, Perdagangan dan Perindustrian Kabupaten Sumedang bukan hanya mengkonsentrasikan terhadap kemampuan atas kepentingan efesiensi, akan tetapi hendaknya juga mempunyai perhatian yang serius agar bekerja keras melakukan mengelola pasar tradisional di Kabupaten Sumedang secara lebih baik dan efektif.

\section{Strategi}

Strategi Dinas Koperasi, UKM, Perdagangan dan Perindustrian Kabupaten Sumedang merupakan rumusan perencanaan komprehensif tentang bagaimana Dinas Koperasi, UKM, Perdagangan dan Perindustrian Kabupaten Sumedang akan mencapai misi dan tujuannya. Strategi akan memaksimalkan keunggulan kompetitif dan meminimalkan keterbatasan bersaing.

Strategi yang selama ini dilakukan oleh

Dinas Koperasi, UKM, Perdagangan, dan 
Perindustrian adalah: peningkatan kemampuan pengelolaan usaha KUMKM/LKM; peningkatan pengetahuan di bidang teknis, manajemen dan legalitas usaha; peningkatkan produktivitas, kreativitas dan inovasi kweirausahaan melalui penguatan kelembagaan ekonomi rakyat; peningkatan ekspor produk unggulan daerah; peningkatan kemampuan dan penguasaan pengetahuan di bidang teknologi industri; peningkatan promosi dan pameran produk unggulan UMKM/IKM/LKM kreatif; peningkatan pemasaran dan perdagangan dalam negeri melalui promosi dan penetrasi pasar baru, penggunaan produk dalam negeri khususnya produk lokal; peningkatan kemitraan kerjasama kelembagaan usaha; peningkatan terbentuknya klaster-klaster industri dan embrio-embrio industri potensial; peningkatan pengetahuan konsumen atas hak dan kewajibannya serta pemantauan distribusi dan perkembangan harga kebutuhan pokok masyarakat; peningkatkan kualitas infrastruktur, sarana dan prasarana penggerak ekonomi masyarakat; dan peningkatan embrio penggerak ekonomi masyarakat.

Para pedagang memberikan tanggapan yang beragam mengenai pengelolaan pasar tradisional yang dilakukan oleh pihak Dinas Koperasi, UKM, Perdagangan, dan Perindustrian. Ketua Ikwapa Kabupaten Sumedang mengatakan bahwa sebelumnya telah ada sosialisasi aturan-aturan yang berhubungan dengan perdagangan.

Dengan demikian, strategi pengelolaan pasar tradisional yang dilakukan oleh Dinas
Koperasi, UKM, Perdagangan, dan Perindustrian Kabupaten Sumedang, dengan merujuk kepada pendapat Glueck dan Jauch (Saladin, 2001: 1), "strategi adalah sebuah rencana yang disatukan, luas dan terintegrasi, yang menghubungkan keunggulan strategi perusahaan dengan tantangan lingkungan dan yang dirancang untuk memastikan bahwa tujuan utama perusahaan dapat dicapai melalui pelaksanaan yang tepat oleh organisasi", artinya strategi yang ada belum sepenuhnya menjadi rencana yang disatukan, luas, terintegrasi dan sistematis, karena belum menghubungkan keunggulan yang dimiliki Dinas Koperasi, UKM, Perdagangan, dan Perindustrian Kabupaten Sumedang dikaitkan dengan tantangan lingkungan yang ada, dan belum sepenuhnya dirancang untuk memastikan bahwa tujuan utama pengelolaan pasar tradisional di Kabupaten Sumedang dapat dicapai melalui pelaksanaan yang tepat oleh Dinas Koperasi, UKM, Perdagangan, dan Perindustrian Kabupaten Sumedang.

Dari data dan paparan tersebut di atas, dapat di analisis bahwa ada beberapa hal penting yaitu belum adanya suatu rencana tindakan yang dirancang Dinas Koperasi, UKM, Perdagangan, dan Perindustrian Kabupaten Sumedang untuk mencapai tujuan pengelolaan pasar tradisional bukan hanya tujuan jangka pendek, akan tetapi juga jangka menengah dan jangka panjang.

Untuk menyusun strategi pengelolaan pasar tradisional yang dilakukan oleh Dinas Koperasi, UKM, Perdagangan dan Perindustrian Kabupaten Sumedang, 
diperlukan analisis terhadap lingkungan Kabupaten Sumedang, baik lingkungan internal maupun eksternal, yaitu peluang dan ancaman/tantangan bagi pasar tradisional, maupun kekuatan dan kelemahan yang ada pada pasar tradisional. Hal-hal ini belum sepenuhnya dilakukan oleh Dinas Koperasi, UKM, Perdagangan, dan Perindustrian Kabupaten Sumedang, sebenarnya hal ini penting untuk mengantisipasi perubahanperubahan yang terjadi di Kabupaten Sumedang.

Analisis berikutnya adalah strategi yang dilakukan oleh Dinas Koperasi, UKM, Perdagangan dan Perindustrian Kabupaten Sumedang dalam mengelola pasar tradisional memerlukan suatu keputusan pilihan dan pelaksanaan yang tepat dan terarah guna mencapai tujuan pengelolaan pasar tradisional di Kabupaten Sumedang. Menurut Kuncoro (2006), "strategi adalah sejumlah keputusan dan aksi yang ditunjukkan untuk mencapai tujuan (goal) dan menyesuaikan sumber daya organisasi dengan peluang dan tantangan yang dihadapi dalam lingkungan industrinya". Strategi pengelolaan pasar tradisional seharusnya dirancang untuk menjamin agar tujuan dan sasaran Dinas Koperasi, UKM, Perdagangan, dan Perindustrian Kabupaten Sumedang dapat dicapai melalui langkahlangkah yang tepat.

\section{Kebijakan}

Kebijakan pengelolaan pasar tradisional memberikan pedoman yang luas untuk pengambilan keputusan Dinas Koperasi, UKM, Perdagangan, dan Perindustrian Kabupaten
Sumedang secara keseluruhan. Kebijakan merupakan landasan yang menghubungkan perumusan strategi dan implementasi yang dilakukan oleh Dinas Koperasi, UKM, Perdagangan dan Perindustrian Kabupaten Sumedang dalam mengelola pasar tradisional.

Kebijakan yang dilakukan oleh Dinas Koperasi, UKM, Perdagangan, dan Perindustrian Kabupaten Sumedang dalam merumuskan strategi sehingga pengelolaan pasar tradisional di Kabupaten Sumedang dapat dilaksanakan adalah melaksanakannya sesuai dengan aturan yang ada. Dinas Koperasi, UKM, Perdagangan, dan Perindustrian Kabupaten Sumedang memberikan pengarahan khususnya mengenai penempatan para pedagang yang tidak sesuai dengan aturan. Dinas Koperasi, UKM, Perdagangan, dan Perindustrian Kabupaten Sumedang mengarahkan agar para pedagang pasar tradisional di Kabupaten Sumedang dapat menempati tempat-tempat yang sudah disediakan.

Peraturan untuk pengelolaan pasar tradisional yang dikeluarkan oleh Dinas Koperasi, UKM, Perdagangan, dan Perindustrian Kabupaten Sumedang sudah cukup banyak. Diantaranya adalah mengenai pelayanan pasar tradisional di Kabupaten Sumedang, petugas-petugas pasar tradisional di Kabupaten Sumedang, di samping itu ada pembinaan-pembinaan para pedagang pasar tradisional di Kabupaten Sumedang melalui pelatihan-pelatihan. Pembinaan kepada pedagang dan petugas pasar tradisional di Kabupaten Sumedang itu dibina secara rutin 
oleh Dinas Koperasi, UKM, Perdagangan, dan Perindustrian Kabupaten Sumedang. Ada pula yang dilakukan dengan bentuk himbauan agar timbul kebersamaan dan kegotongroyongan, seperti mengelola sampah diupayakan gotong royong, bukan hanya merupakan tugas dari petugas kebersihan pasar tradisional di Kabupaten Sumedang, tapi semua merasa itu tugas dari semua pedagang pasar tradisional di Kabupaten Sumedang.

Kebijakan yang ada dalam pengelolaan pasar tradisional di Kabupaten Sumedang belum seiring dengan pendapat yang dikemukakan oleh Dye, Edward III, dan Sharkansky (Islamy, 1997) yang menyatakan bahwa "kebijakan publik adalah apa yang dikatakan dan dilakukan pemerintah, atau yang tidak dilakukannya". Kebijakan pengelolaan pasar tradisional di Kabupaten Sumedang itu seharusnya merupakan suatu sasaran atau tujuan dari program Pemerintah Kabupaten Sumedang, sehingga dibuat dalam level yang lebih tinggi sampai level teknis. Kebijakan dalam rangka manajemen strategis yang dilakukan oleh Dinas Koperasi, UKM, Perdagangan dan Perindustrian Kabupaten Sumedang dalam mengelola pasar tradisional dengan merujuk kepada pendapat Anderson (Islamy, 1997) belumlah menjadi kebijakan publik yang menjadi serangkaian tindakan yang mempunyai tujuan tertentu yang diikuti dan dilaksanakan oleh para pedagang pasar tradisional di Kabupaten Sumedang atau stake holder lainnya di pasar-pasar tradisional di Kabupaten Sumedang guna memecahkan berbagai masalah yang ada pengelolaan pasar tradisional di Kabupaten Sumedang.

Berbagai kenyataan dalam pengelolaan pasar-pasar tradisional di Kabupaten Sumedang tersebut belum dapat menunjukkan gambaran yang lengkap mengenai suatu kebijakan publik, sebab pengertian tindakantindakan atau keputusan-keputusan yang dibuat oleh Pemerintah Kabupaten Sumedang tidak secara eksplisit dijelaskan dalam bentuk kebijakan yang terdokumentasikan. Namun demikian, dapat ditarik satu kesamaan bahwa kebijakan pengelolaan Pasar Tradisional di Kabupaten Sumedang merupakan tindakantindakan atau keputusan-keputusan yang dibuat oleh Pemerintah Kabupaten Sumedang dalam hal ini Dinas Koperasi, UKM, Perdagangan dan Perindustrian di Kabupaten Sumedang.

Selanjutnya peneliti mengutip pendapat mengenai kebijakan publik menurut Jenkins (Wahab, 2002) yang menjelaskan bahwa kebijakan publik sebagai $a$ set of interrelated decisions taken by political actor or group of actor concerning the selection of goals and the means of achieving them within a specified situation where these decisions should in principle, be within the power of these actor to achive, maka bisa jadi political actor or group of actor di Kabupaten Sumedang sampai saat ini belum mempunyai concerning the selection of goals dalam pengelolaan pasar tradisional, sehingga decisions should in principle, be within the power of these actor to achive sama sekali tidak terwujudkan dalam manajemen strategis yang dilakukan oleh Dinas Koperasi, UKM, 
Perdagangan dan Perindustrian Kabupaten Sumedang dalam mengelola pasar tradisional.

Kemudian dengan merujuk kepada pendapat Mustopadidjaya (2003) yang mengemukakan "kebijakan publik sebagai keputusan atau berbagai peraturan", maka manajemen strategis yang dilakukan oleh Dinas Koperasi, UKM, Perdagangan dan Perindustrian Kabupaten Sumedang dalam mengelola pasar tradisional belumlah merupakan keputusan yang jelas yang dilakukan oleh pejabat Pemerintah Kabupaten Sumedang atas nama instansi yang dipimpinnya dalam rangka mengelola pasar tradisional di Kabupaten Sumedang; guna mengatasi masalah pengelolaan pasar tradisional atau untuk mencapai tujuan pengelolaan pasar tradisional, ataupun dalam rangka melaksanakan produk-produk keputusan atau peraturan pengelolaan pasar tradisional yang telah ditetapkan, dan kebijakan ini selazimnya dituangkan dalam bentuk peraturan daerah atau bentuk keputusan formal Dinas Koperasi, UKM, Perdagangan, dan Perindustrian Kabupaten Sumedang.

Pembuat kebijakan, tujuan kebijakan, petunjuk untuk melakukannya, dan keputusan-keputusan yang dipilih terkait manajemen strategis yang dilakukan oleh Dinas Koperasi, UKM, Perdagangan dan Perindustrian Kabupaten Sumedang dalam mengelola pasar tradisional seharusnya dituangkan dalam bentuk peraturan yang tegas. Hal ini sejalan dengan apa yang dikatakan Wibawa (1994) tentang "operasionalisasi kebijakan itu harus dijabarkan ke dalam program-program yang didalamnya mengandung langkah-langkah yang akan dilakukan". Program harus mencerminkan tugas pokok dan fungsi yang dilaksanakan oleh Dinas Koperasi, UKM, Perdagangan, dan Perindustrian Kabupaten Sumedang, berkaitan dengan kebijakan serta program Pemerintah Kabupaten Sumedang.

Sementara itu kebijakan terkait manajemen strategis yang dilakukan oleh Dinas Koperasi, UKM, Perdagangan dan Perindustrian Kabupaten Sumedang dalam mengelola pasar tradisional yang melibatkan kepentingan masyarakat, dengan merujuk kepada pendapat Wibawa (1994) seyogyanya kebijakan pengelolaan pasar tradisional adalah serangkaian pilihan tindakan Pemerintah Kabupaten Sumedang untuk menjawab tantangan (atau pemecahan masalah) kehidupan masyarakat Kabupaten Sumedang itu sendiri. Dengan demikian, kebijakan pengelolaan pasar tradisional di Kabupaten Sumedang merupakan keputusan yang dilakukan oleh pejabat Pemerintah Kabupaten Sumedang atas nama instansi yang dipimpinnya dalam rangka melaksanakan fungsi pemerintahan ataupun pembangunan di Kabupaten Sumedang.

Berdasar pada paparan di atas, dapat di analisis bahwa kebijakan pengelolaan pasar tradisional tersebut seyogyanya dituangkan dalam bentuk aturan perundangan atau bentuk keputusan formal tertentu yang dimulai dari level peraturan tinggi sampai terendah atau tataran teknis baik dalam 
bentuk SOP atau juklak-juknis. Tidak seperti sekarang ini, perda yang mengatur tentang pengelolaan pasar tradisional sudah mengalami perubahan namun perbupnya belum mengalami perubahan. Padahal idelanya jika aturan di atasnya berubah, maka aturan di bawahnya turut menyesuaikan sehingga terjadi korelasi yang baik dalam pelaksanaan kebijakan tersebut. Menurut Lubis (2000), yang dimaksud dengan peraturan negara (staatsregelings) adalah: "peraturan-peraturan tertulis yang diterbitkan oleh instansi resmi, baik dalam pengertian lembaga maupun dalam pengertian pejabat tertentu. Peraturan yang dimaksud meliputi Undang-Undang, Peraturan Pemerintah Pengganti Undang-Undang, Peraturan Pemerintah, Peraturan Presiden, Peraturan Menteri, Peraturan Daerah, Instruksi, Surat Edaran, Pengumuman, Surat Keputusan, dan lain-lain".

Kebijakan pengelolaan pasar tradisional tersebut disusun dengan maksud untuk memecahkan masalah dalam kehidupan masyarakat Kabupaten Sumedang, dan juga dengan maksud untuk mengubah perilaku warga Kabupaten Sumedang, terutama kepada para pedagang di pasar-pasar tradisional di Kabupaten Sumedang dengan memberlakukan sanksi yang mendidik dan berdampak efek jera.

\section{SIMPULAN}

Dalam hal perumusan strategi menunjukkan: a) tujuan perbaikan/revitalisasi dari sembilan (9) pasar tradisional yang ada di
Kabupaten Sumedang baru empat (4) pasar atau sekitar 30\% yang dapat direvitalisasi dan rendahnya SDM serta tingkat kesadaran para pedagang Pasar Tradisional di Kabupaten Sumedang; b) strategi yang ada belum sepenuhnya menjadi rencana yang disatukan, luas, terintegrasi dan sistematis, karena belum menghubungkan keunggulan yang dimiliki Dinas Koperasi, UKM, Perdagangan, dan Perindustrian Kabupaten Sumedang dikaitkan dengan tantangan lingkungan yang ada; c) kebijakan teknis berupa perbup belum mengalami perubahan padahal perda yang mengatur pengelolaan Pasar Tradisional di Kabupaten sudah mengalami perubahan cukup lama.

\section{DAFTAR PUSTAKA}

Drucker, P.F. (2000). Pemimpin masa depan. Jakarta: PT Elex Media Komputindo.

Hunger, J.D. and Wheelen, T.L. (2003). Manajemen Strategis. Terjemahan: Agung, Julianto. Yogyakarta: Andi.

Islamy, I. (1997). Prinsip-Prinsip Perumusan Kebijaksanaan Negara. Jakarta: Penerbit PT Bumi Aksara.

Kuncoro, M. (2006). Strategi: Bagaimana Meraih Keunggulan Kompetitif. Jakarta: Erlangga.

Lubis. M.S. (2000). Reformasi Politik dan Hukum. Bandung: Mandar Madju.

Mankiw, G. (2003). Makro Ekonomi. Jakarta: Erlangga. Responsif. Bandung: Hakim Publishing.

Moleong. (2007). Metode Penelitian Kualitatif. Bandung: Rosda

Sugiyono. (2014). Metode Penelitian Pendidikan Pendekatan Kuantitatif, Kualitatif, dan R\&D. Bandung: Alfabeta.

Wibawa, S. Purbokusumo, Y. dan Pramusinto, A. (1994). Evaluasi Kebijakan Publik. Jakarta: PT. Raja Grafindo Persada.

Peraturan Presiden Republik Indonesia Nomor 112 Tahun 2007. Tentang Penataan Dan Pembinaan Pasar Tradisional, Pusat Perbelanjaan Dan Toko Modern.

Peraturan Menteri Dalam Negeri Nomor 20 tahun 2012. Tentang pengelolaan dan pemberdayaan pasar tradisional. 
Peraturan Menteri Perdagangan Republik Indonesia Nomor: 70/MDAG/PER/12/2013. Tentang Pedoman Penataan dan Pembinaan Pasar Tradisional, Pusat Perbelanjaan dan Toko Modern.

Peraturan Daerah No.3 Tahun 2014. Tentang Pengelolaan Dan Pemberdayaan Pasar Tradisional Serta Penataan Pusat Perbelanjaan Dan Toko Modern di Kabupaten Sumedang.
RENSTRA Dinas Koperasi, UKM, Perdagangan dan Perindustrian Kabupaten Sumedang Tahun 2014-2018. 